Pesq. Vet. Bras. 35(7):685-690, julho 2015 DOI: $10.1590 / \mathrm{S} 0100-736 \mathrm{X} 2015000700014$

\title{
Glial cells of the central nervous system of Bothrops jararaca (Reptilia, Ofidae): an ultrastructural study ${ }^{1}$
}

\author{
Eduardo F. Bondan ${ }^{2,3 *}$, Maria de Fátima M. Martins ${ }^{2,3}$, Rita Sinigaglia-Coimbra ${ }^{4}$, Rose \\ Eli G. Rici ${ }^{5}$, Maria Angélica Miglino ${ }^{5}$, Dominguita L. Graca ${ }^{6}$ and Rogério L. Zacariotti ${ }^{3}$ \\ ABSTRACT.- Bondan E.F., Martins M.F.M., Sinigaglia-Coimbra R., Rici R.E.G., Miglino M.A., \\ Graca D.L. \& Zacariotti R.L. 2015. Glial cells of the central nervous system of Bothrops \\ jararaca (Reptilia, Ofidae): an ultrastructural study. Pesquisa Veterinária Brasileira \\ 35(7):685-690. Departamento de Patologia Ambiental e Experimental, Universidade Pau- \\ lista, Rua Luís Góis 2211, São Paulo, SP 04043-200, Brazil. E-mail: bondan@uol.com.br \\ Although ultrastructural characteristics of mature neuroglia in the central nervous sys- \\ tem (CNS) are very well described in mammals, much less is known in reptiles, especially \\ serpents. In this context, two specimens of Bothrops jararaca were euthanized for morpho- \\ logical analysis of CNS glial cells. Samples from telencephalon, mesencephalon and spinal \\ cord were collected and processed for light and transmission electron microscopy investi- \\ gation. Astrocytes, oligodendrocytes, microglial cells and ependymal cells, as well as myelin \\ sheaths, presented similar ultrastructural features to those already observed in mammals \\ and tended to maintain their general aspect all over the distinct CNS regions observed. \\ Morphological similarities between reptilian and mammalian glia are probably linked to \\ their evolutionary conservation throughout vertebrate phylogeny.
}

INDEX TERMS: Bothrops jararaca, central nervous system, glia cells, reptiles, ultrastructure.

RESUMO.- [Células gliais do sistema nervoso central de Bothrops jararaca (Reptilia, Ofidae): um estudo ultraestrutural.] Muito embora as características ultraestruturais da neuróglia madura do sistema nervoso central (SNC) sejam bem descritas em mamíferos, muito pouco é conhecido em répteis, especialmente em serpentes. Neste contexto, dois espécimes de Bothrops jararaca foram eutanasiados para análise morfológica das células gliais presentes no SNC. Amostras de telencéfalo, mesencéfalo e medula espinhal foram coletadas e processadas para investigação

\footnotetext{
${ }^{1}$ Received on March 17, 2015.

Accepted for publication on July 9, 2015.

${ }^{2}$ Departamento de Patologia Experimental e Ambiental, Universidade Paulista (Unip), Rua Luís Góis 2211, São Paulo, SP 04043-200, Brazil. *Corresponding author: bondan@uol.com.br

${ }^{3}$ Departamento de Medicina Veterinária, Universidade Cruzeiro do Sul, Av. Dr. Ussiel Cirilo 225, São Paulo, SP 08060-070.

${ }^{4}$ Centro de Microscopia Eletrônica, Universidade Federal de São Paulo (Unifesp), Edifício de Ciências Biomédicas, Rua Botucatu 862, São Paulo, SP 04023-062.

${ }^{5}$ Departamento de Cirurgia, Faculdade de Medicina Veterinária, Universidade de São Paulo (USP), Av. Prof. Dr. Orlando Marques de Paiva 87, São Paulo, SP 05508-270.

${ }^{6}$ Departamento de Patologia, Universidade Federal de Santa Maria (UFSM), Av. Roraima 1000, Camobi, Santa Maria, RS 97105-900, Brazil.
}

por microscopia de luz e eletrônica de transmissão. Astrócitos, oligodendócitos, células microgliais e ependimárias, bem como bainhas de mielina, apresentaram características ultraestruturais similares àquelas já observadas em mamíferos e tenderam a manter seu aspecto geral pelas diferentes regiões observadas no SNC. Similaridades morfológicas entre as células gliais de mamíferos e de répteis estão provavelmente ligadas a sua conservação evolutiva ao longo da filogenia dos vertebrados.

TERMOS DE INDEXAÇÃO: Bothrops jararaca, SNC, glia, répteis, ultraestrutura.

\section{INTRODUCTION}

Bothrops jararaca (Wied, 1824) is a not threatened and slender, terrestrial pit viper that feeds on rodents, frogs, lizards and centipedes. This species occurs in southeastern South America, from State of Bahia to the State of Rio Grande do Sul in Brazil and northern Argentina. B. jararaca is an important cause of snakebites in Brazil and is abundant in many parts of its geographical range (Campbell \& Lamar 2004).

Throughout the nervous tissue of invertebrates and vertebrates, neurons are invariably found in close association with glial cells (or glia-like cells in primitive animals, with 
very simple cellular organization). The term glia includes nonneuronal cells known to play several functions in the maintenance of neural homeostasis in both central (CNS) and peripheral (PNS) nervous system. The main glial cell types are, in the CNS, astrocytes, oligodendrocytes and microglia and, in the PNS, Schwann cells, enteric glial cells and satellite cells (Jessen 2004, Kettenmann \& Verkhratsky 2008, Bradl \& Lassmann 2010, Sofroniew \& Vinters 2010). Evolutionary origins of glia are possibly linked to organizational needs, including structural support, by-product removal, phagocytic functions, developmental programming and circuit modulation. Glia probably evolved from neuroectodermal cells, possibly from a mobile lineage or independently in different regions of the body, having multiple functions in both developing and mature nervous system (Allen \& Barres 2009, Hartline 2011). A notable exception is microglia, which are part of the immune system and enter the CNS from blood circulation early in an organism's development (Allen \& Barres 2009).

Although ultrastructural characteristics of mature neuroglia in the mammalian CNS are now well established (Peters et al. 1991), little attention has been paid to glial cells in reptiles, especially in serpents. In reptiles, all available information is practically restricted to lizards of the genus Gallotia (Tenerife lizards or Western Canaries lizards) (Garcia-Verdugo et al. 1981, 1986, Monzon-Mayor et al. 1990a,b). Besides the normal functions developed by glial cells in the CNS, several lines of evidence indicate that in reptiles radial glial cells act as stem cells for adult neurogenesis (Font et al. 2001). Radial glia is generated before neurogenesis and guide neuronal migration in the developing brain. In mammals, radial glial cells disappear or become astrocytes within days to weeks after birth, but in non-mammals they persist into adulthood as radial glia (Lazzari \& Franceschini 2001, Weissman et al. 2003).

Despite the recent and remarkable progresses in the study of glial cells in the mammalian CNS and the fact that reptiles are the earliest amniotes, ultrastructural studies on reptilian neuroglia are still very scarce. In such context, this investigation aims to describe morphological aspects of glial cells as seen in transmission electron microscopy in the CNS of adult specimens of this pit viper species.

\section{MATERIALS AND METHODS}

Two adult female Bothrops jararaca specimens (mass approximately 125g) were collected (License 17753-3, IBAMA/SISBIO - Authorization and Information System on Biodiversity, Brazil) and euthanized using a dose of $500 \mathrm{mg} / \mathrm{kg}$ of ketamine and $20 \mathrm{mg} / \mathrm{kg}$ of xylazine intramuscularly. After 25 minutes, the snakes presented mydriatic pupils and had lost the following reflexes - righting reflex, tail pinch reflex, tongue withdrawal reflex and vent stimulation reflex. A surgical incision was made in the ventral scales located close to the final of the first third of their bodies, around the 60 th ventral scale, the anatomical position of the heart (Gomes \& Puorto 1993). After minor dissection around the heart the anterior vena cava and aorta were both cannulated using 24G catheters. A $4 \%$ glutaraldehyde solution in 0.1 M Sorensen phosphate buffer (pH 7.4) was infused through aorta until a clear solution was obtained from the anterior vena cava.

After the infusion of fixative solution the skull and the cervi- cal vertebrae were dissected for removal of brain and spinal cord, respectively. Thin slices of the telencephalon, mesencephalon and spinal cord were collected and post-fixed in 1\% osmium tetroxide, dehydrated with graded acetones and embedded in Araldite 502 resin, following transitional stages in acetone. Thick sections were stained with $0.25 \%$ alkaline toluidine blue. Selected areas were trimmed and thin sections were stained with $2 \%$ uranyl acetate and lead citrate and examined using a JEOL JEM-1200EX II transmission electron microscope. Myelin periodicity was analysed using the ImageJ image processing program (National Institutes of Health - NIH, Bethesda, Maryland, USA).

\section{RESULTS}

The different types of glial cells identified in this investigation tended to maintain their ultrastructural characteristics all over the different CNS regions collected for observation. Oligodendrocytes exhibited a wide spectrum of morphological variation involving their cytoplasmic density and clumping of nuclear chromatin. They appeared as lightly or moderately dense cells with a round, oval or irregular nucleus, whose chromatin tended to clump (Fig.1A,B). In the perikaryon the Golgi apparatus and the rough surfaced endoplasmic reticulum (whose cisternae were sometimes arranged in long and parallel rows) were well developed. Mitochondria were also easily seen. They had few cytoplasmic fibrils and glycogen granules, although microtubules were conspicuous.

Astrocytes appeared as homogeneous cells in density and irregular in shape, with cytoplasmic organelles relatively sparse. The nuclei tended to be irregular in shape with fine clumps of chromatin scattered throughout the nucleoplasm and small chromatin patches around the nuclear envelope. Occasionally a nucleolus was evident. The most prominent cytoplasmic component of the astrocyte was the numerous fibrils or filaments that occurred throughout the perikaryon and extended as parallel arrays into the processes (Fig.2A,B).

Myelinated axons (Fig.3A) containing microtubules and neurofilaments were seen. The characteristic spiraled lamellae were clearly noted beginning at the internal mesaxon, as well as the intraperiod line (produced by the apposition of the outer leaflets of two portions of the plasma membrane of the oligodendrocyte) and, alternating with the intraperiod line, the major dense line (formed by apposition between the inner leaflets of the same plasma membrane). The two lines continued in a spiral and terminated on the outside of the sheath. The repeating distance between the centers of dense lines (known as myelin periodicity, Fig.3B) was $11 \mathrm{~nm}$ in both spinal cord and brain myelin.

Some quiescent microglial-like cells were noted beneath the glia limitans and in the vicinity of blood vessels where they lied adjacent to astrocytic end-feet surrounding capillaries (Fig.4). They appeared smaller than oligodendrocytes and astrocytes and presented elongate nuclei, with clumps of chromatin beneath the nuclear envelope and throughout the nucleoplasm. The cytoplasm appeared as a dark thin rim around the nucleus, but often extending out in quite broad processes. In the scanty perikaryon long and narrow cisternae of the granular endoplasmic reticulum were identified, often seen to wind tortuously through the cytoplasm. 
Ependyma was observed as a single layer of squamous, cuboidal or columnar cells around ventricles, the cerebral aqueduct and the central canal of the spinal cord (Fig.5A). Their nuclei were light with chromatin evenly dispersed and had an irregular or oval shape, occupying a large portion of the cell volume, usually in a basal position. The cytoplasm contained the usual organelles, as well as thin filaments often aggregated into bundles. At the apical ends ependymal cells presented short microvilli and a tuft of cilia. Cilia arose from basal bodies located in the apical cytoplasm and tended to be clustered toward the center of the free surface of the cell. Each one contained nine peripheral pairs of microtubules surrounding a central pair, the common pattern of most cilia (Fig.5B). At the ventricular and basal ends of ependymal cells there was a series of zonullae adhaerentes between them. In the subependymal layer there were small and dark cells having nuclei with clumped chromatin, as well as cells with pale nuclei (Fig.6).

In subpial areas it was noticed a great number of
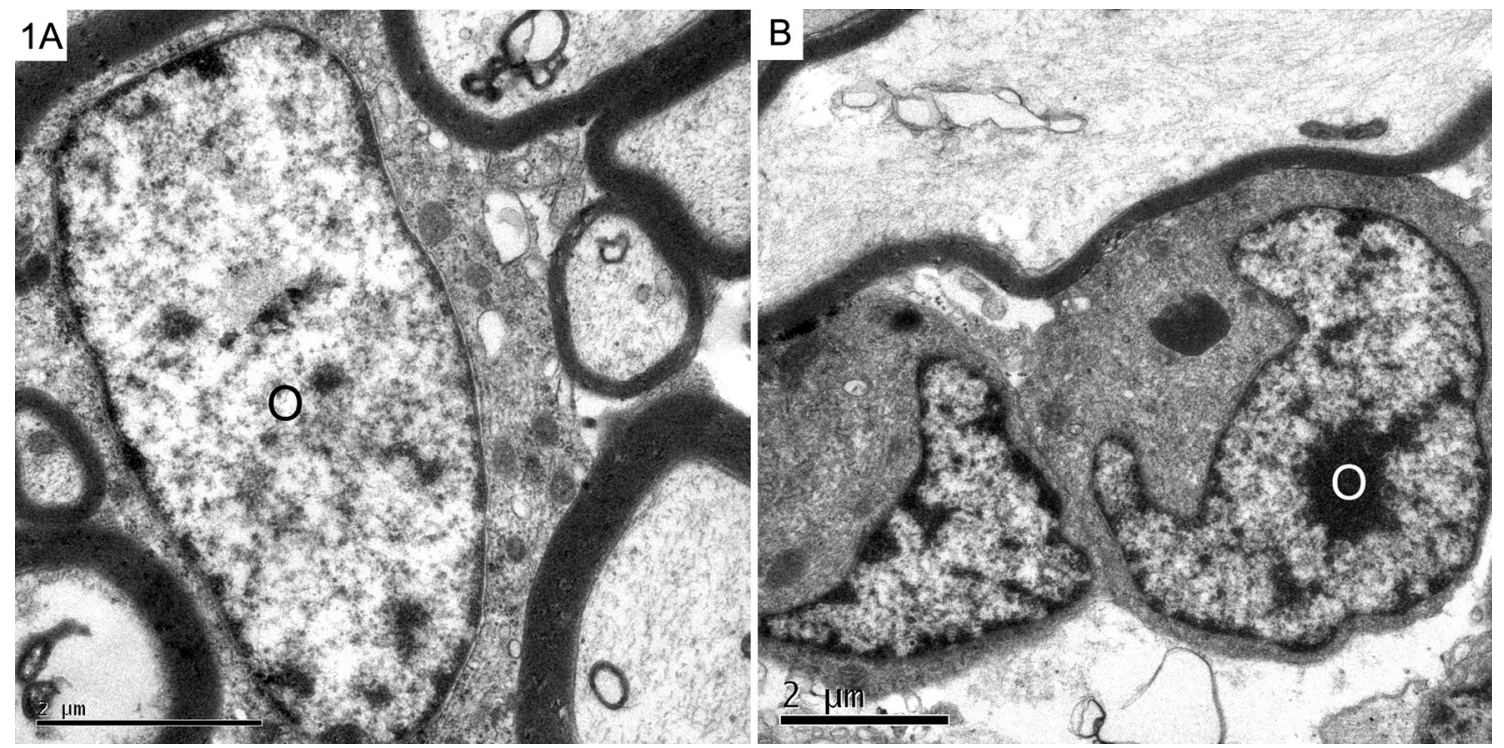

Fig.1. (A) A light and (B) two dark oligodendrocytes (0) near myelinated axons in the mesencephalon of a Bothrops jararaca specimen. (A) The palely staining cytoplasm contained free ribossomes, numerous mitochondria, a Golgi complex and microtubules. (B) The cytoplasm appeared to be more electron-dense and nuclear chromatin tended to be arranged in clumps. In both oligodendrocyte types it is not unusual for the cistern of the nuclear envelope and the cisternae of the granular endoplasmic reticulum to be distended. (A) Bar $=2 \mu \mathrm{m}$; (B) Bar $=2 \mu \mathrm{m}$.
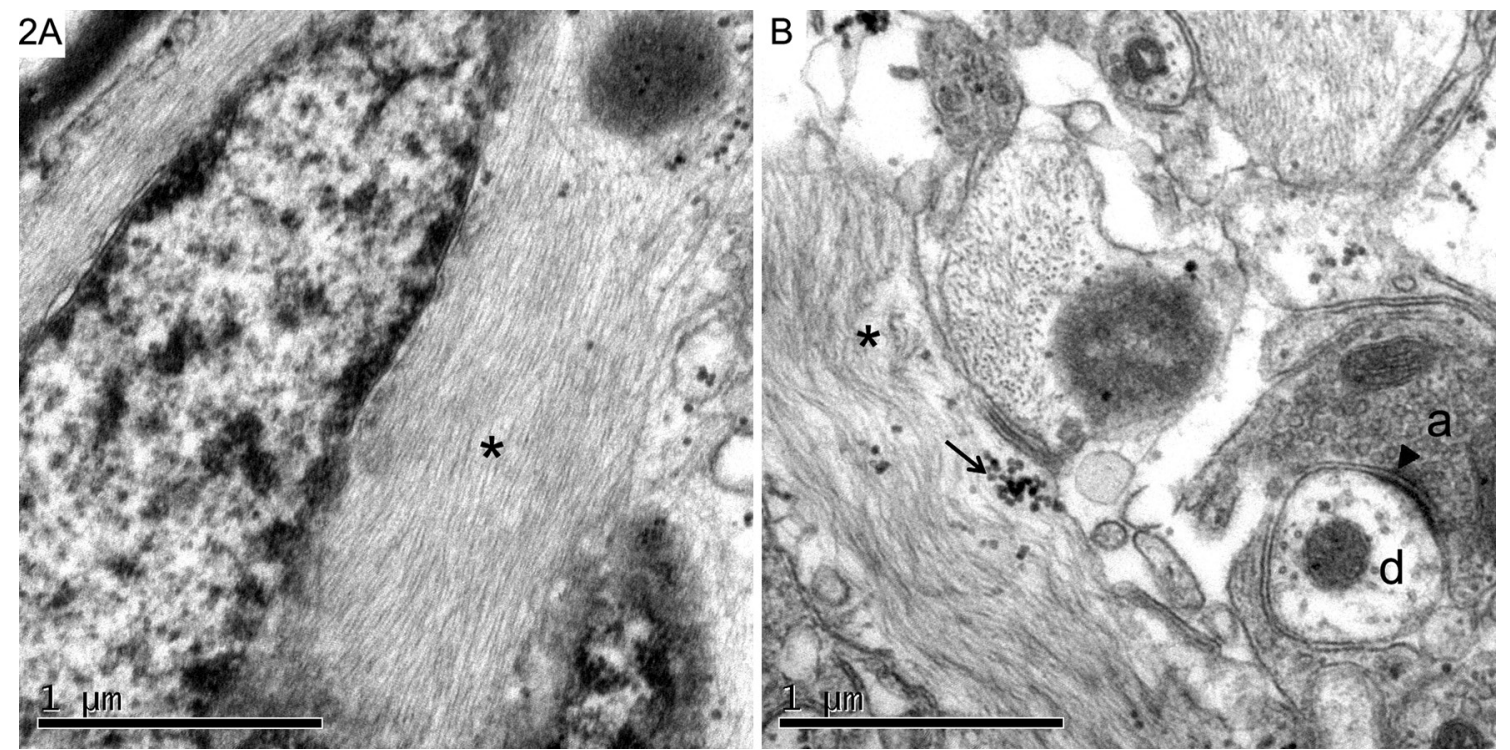

Fig.2. (A) Astrocyte with cytoplasm packed with gliofilaments (asterisk). (B) Astrocytic process presenting large bundles of filaments (asterisk) and some glycogen granules (arrow). It is possible to note a synaptic junction (arrowhead) between a dendrite (d) and an axon terminal (a). The axon terminal contains spherical vesicles and the presynaptic and postsynaptic membranes are separated by a cleft that contains intercellular material. The postsynaptic membrane has a prominent coating of dense material on its cytoplasmic face. (A) Spinal cord. Bar = $1 \mu \mathrm{m}$; (B) Mesencephalon. Bar $=1 \mu \mathrm{m}$. 

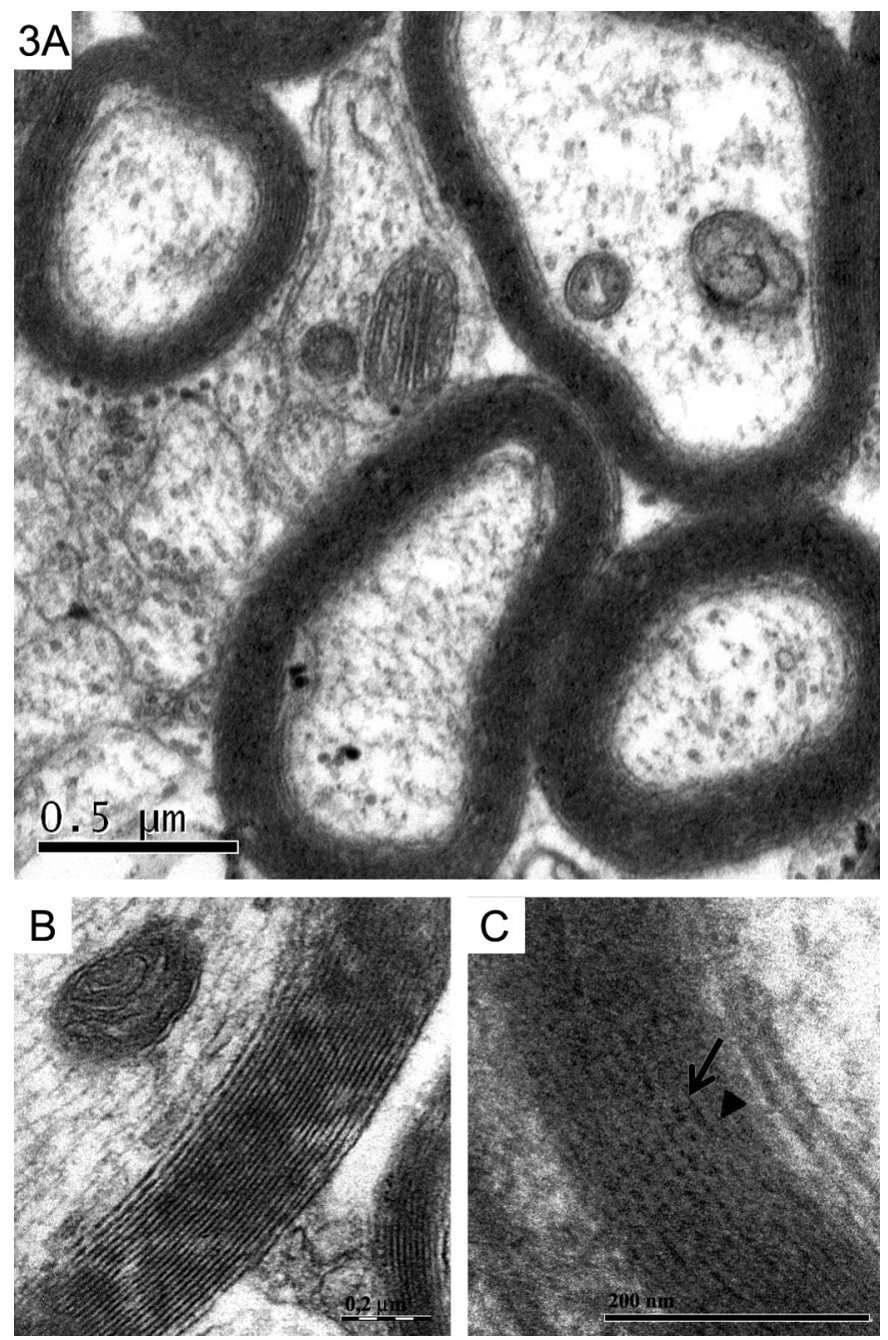

Fig.3. (A) Myelinated axons in spinal cord white matter. (B) In the myelin sheath the alternating lines are visible. (C) At higher magnification a series of alternating lines can be seen, dark (major dense lines - arrow) and less dark (intraperiod lines - arrowhead), separated by unstained zones. (A) Bar=0.5 $\mu \mathrm{m}$; (B) $\operatorname{Bar}=0.2 \mu \mathrm{m}$; (C) Bar $=200 \mathrm{~nm}$. phagocytic-like cells with long processes and also having abundant mitochondria and vesicles in their cytoplasm (Fig.7A,B).

\section{DISCUSSION}

General features of glial cells observed in this investigation resemble those already described in the reptilian (Kruger \& Maxwell 1967, Monzon-Mayor et al. 1990a,b, Peters et al. 1991, Ledda et al. 2004) and mammalian CNS (Mori \& Leblond 1970, Peters et al. 1991). In reptiles, however, these morphological studies are practically restricted to lizards.

Electron micrograph studies of the mammalian CNS

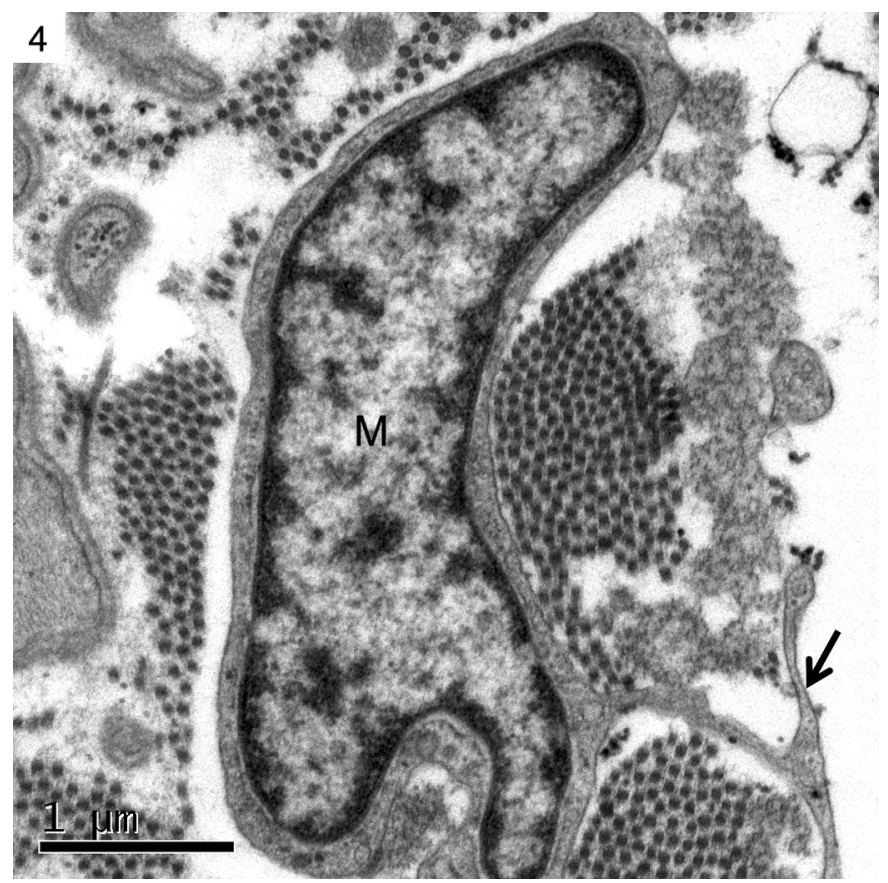

Fig.4. This microglial-like cell (M) has a nucleus with irregular outline in which chromatin is clumped beneath the nuclear envelope and a thin rim of cytoplasm. Note its long and thin processes (arrow). Subpial area of the spinal cord. Bar $=1 \mu \mathrm{m}$.
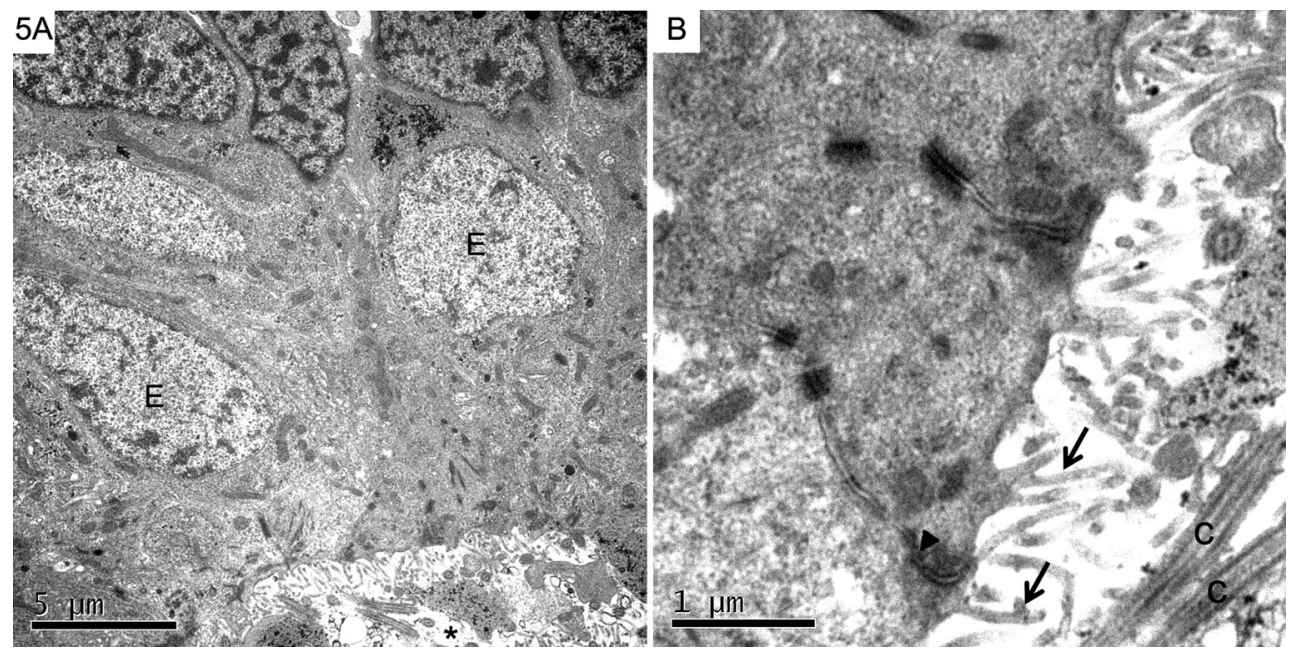

Fig.5. (A) Ependymal cells (E) with light nuclei and homogeneous chromatin lining the walls of the central canal (asterisk) of the spinal cord and above some cells with clumped chromatin. (B) Ependymal cells present at their apical ends short and uneven microvilli (arrows) as well as cilia (C). The apical end of the intercellular junction is marked by zonullae adhaerentes (arrowhead). (A) Bar $=5 \mu \mathrm{m},(\mathrm{B}) \mathrm{Bar}=1 \mu \mathrm{m}$. 


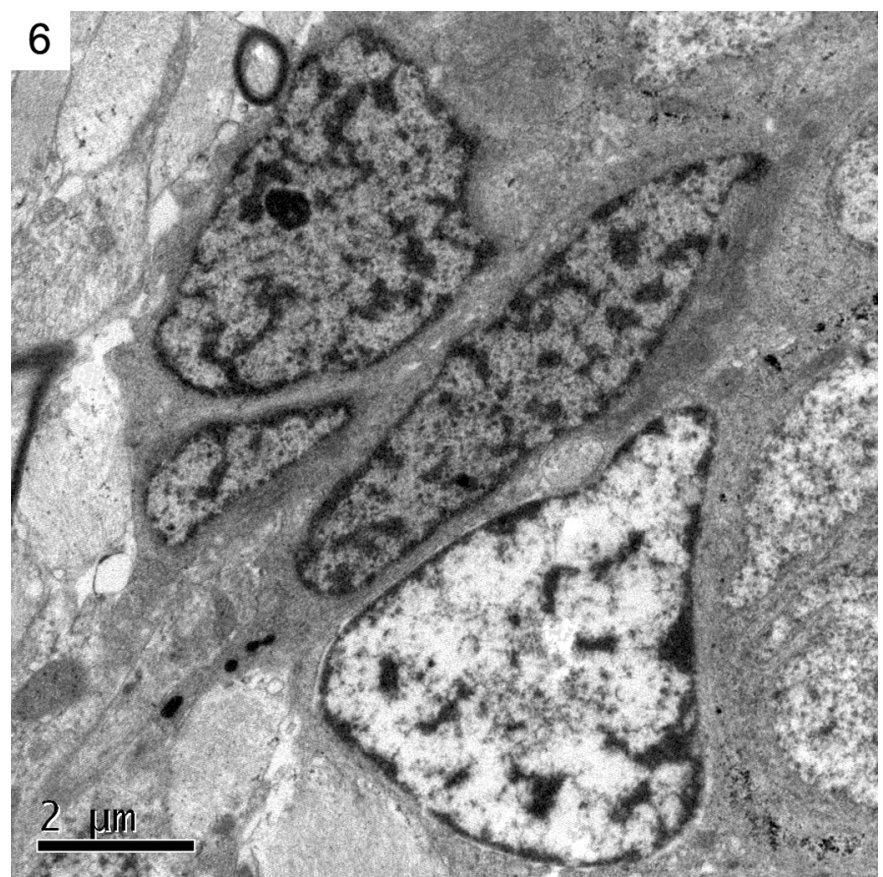

Fig.6. Subependymal layer of the spinal cord with small and dark cells and cells with pale nuclei. Bar $=2 \mu \mathrm{m}$.

have shown that oligodendrocytes present a wide spectrum of electron density (Mori \& Leblond 1970). It was suggested that these cells make up a gradient in which the light oligodendrocytes are the most actively dividing ones and that they become progressively darker as they mature. Thus, light, medium and dark oligodendrocytes represent different stages in oligodendrocyte development and most authors agree that, in the adult, dark oligodendrocytes form the major part of oligodendroglial population.

As for astrocytes it was not possible to distinguish by their ultrastructural characteristics the two usual types (protoplasmic and fibrous) as described in mammals (Peters et al. 1991).

Some features that are helpful to distinguish oligodendrocytes from astrocytes include the greater density of their cytoplasm and nucleus, the absence of fibrils and glycogen in the cytoplasm and the presence of large numbers of microtubules (Peters et al. 1991).

On the other hand, a microglial cell is generally smaller than either an astrocyte or an oligodendrocyte. The density of its cytoplasm, however, parallels that of the oligodendrocyte, but it contains fewer microtubules and has none of the glycogen granules and bundles of filaments that characterize an astrocyte. Perhaps the most distinctive feature of the microglial cell is the aspect of its granular endoplasmic reticulum - while microglial cells exhibit long, narrow and sometimes tortuous cisternae, oligodendrocytes present parallel stacks of short or long cisternae (Peters et al. 1991).

Lining the walls of the ventricles of the brain and the central canal of the spinal cord ependymal cells were observed and beneath them the subependyma was found, separating the ependyma from the underlying periventricular neuropil. Blakemore \& Jolly (1972) have previously studied the ependyma and the subependyma in the anterior part

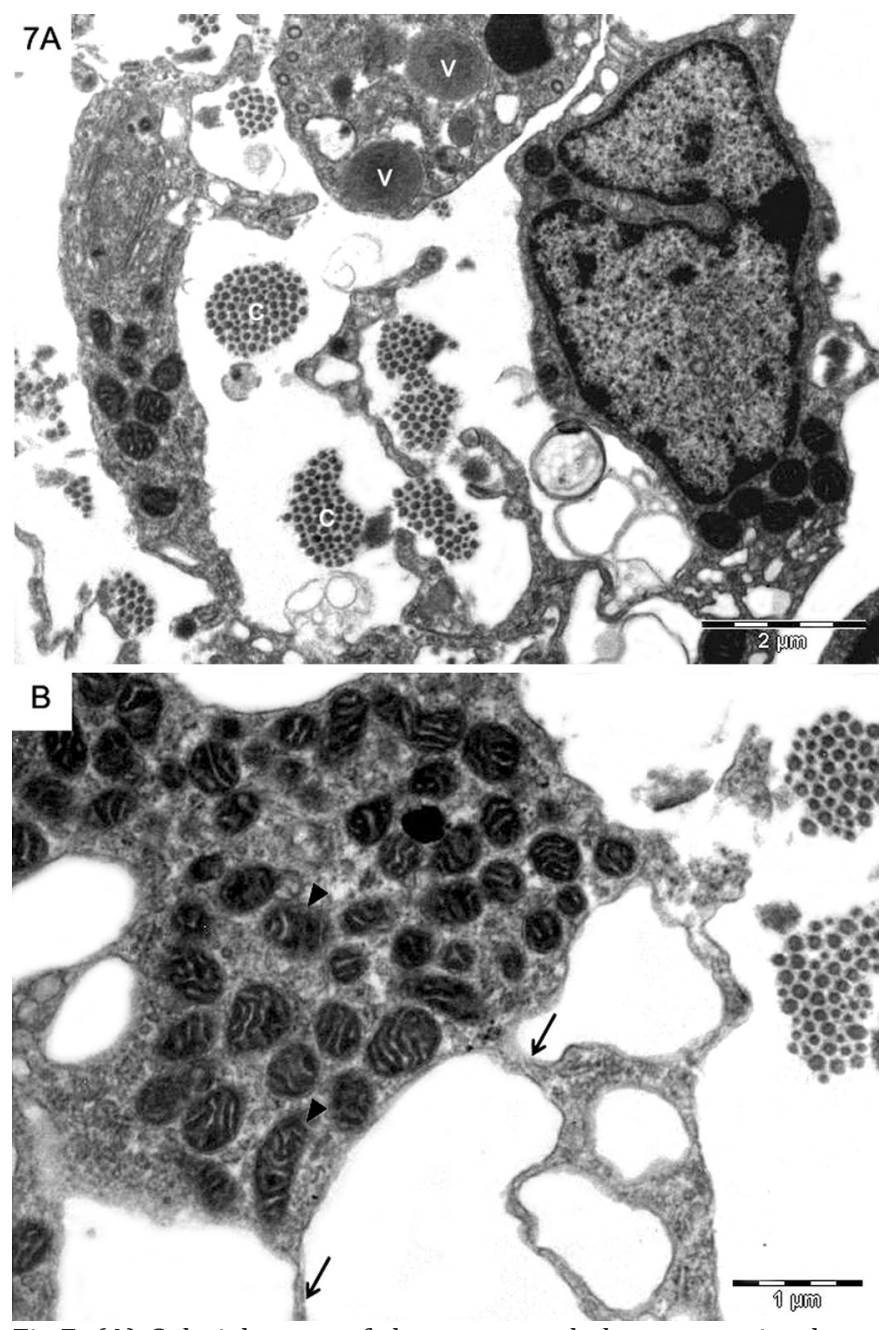

Fig.7. (A) Subpial areas of the mesencephalon presenting large bundles of collagen fibers (c) and phagocytic cells, some of them presenting vesicles (v). (B) Note their thin cytoplasmic processes (arrows) and the large number of mitochondria (arrowheads). (A) Bar $=2 \mu \mathrm{m}$, (B) Bar $=1 \mu \mathrm{m}$.

of the nucleus caudate of the dog describing small and dark cells, often referred to as subependymal plate cells, as well as cells with pale nuclei. This latter group seemed to be composed of astrocytelike cells, tanycytes and ectopic ependymal cells. Similar findings were seen in serpents from this investigation, although, differently from what was reported in the dog, the presence of cells in mitosis was not noted in the subependymal layer. No evidence of radial glia presence was found in the serpents from our study but it is accepted that these cells are hardly observed in transmission electron microscopy studies unless specific markers are used (Weissman et al. 2003). Kamei et al. (1998), for example, have used the Cdc2 kinase-phosphorylated vimentin to identify mitotic radial glial lineage cells in the developing rat brain.

In general, astrocytes and ependymal cells of non-mammalian vertebrates contain greater amounts of glycogen than mammalian cells (Kruger \& Maxwell 1967), but this did not seem to be the case in serpents since glycogen was seen in small quantities in both cells. 
It is known that myelin periodicity observed by transmission electron microscopy is usually less than that calculated from the low-angle $\mathrm{X}$ ray diffraction data, a consequence of the considerable shrinkage that takes place after fixation, dehydration and embedding (Quarles et al. 2006).

Although no cell quantification was done in our study, our findings did not support the observation of Ledda et al. (2004) that reptiles present significantly smaller numbers of neuroglial cells in comparison to mammals. These authors have studied the ratios between the number of neuroglial cells and the number and volume of neurons with which they were associated in the spinal ganglia of two species of reptiles (lizard and gecko) and three species of mammals (mouse, rat and rabbit). The decreased number of glial cells in the reptilian ganglia was then credited to a lower metabolic rate in the nervous system of poikilotherms.

Our results tend to suggest that the morphological similarities noticed in both reptilian and mammalian glia are linked to their evolutionary conservation throughout vertebrate phylogeny.

\section{REFERENCES}

Allen N.J. \& Barres B.A. 2009. Glia - more than just brain glue. Nature 457:675-677.

Bradl M. \& Lassmann H. 2010. Oligodendrocytes: biology and pathology. Acta Neuropathol. 119:37-53.

Blakemore W.D. \& Jolly R.D. 1972. The subependymal plate and associated ependymal in the dog. An ultrastrucutural study. J. Neurocytol. 1:69-84.

Campbell J.A. \& Lamar W.W. 2004. The venomous reptiles of the Western hemisphere. Vol.2. Cornell University Press, Ithaca.

Font E., Desfillis E., Perez-Canellas M.M. \& Garcia-Verdugo J.M. 2001. Neurogenesis and neuronal regeneration in the adult reptilian brain. Brain Behav. Evol. 58:276-295.

Garcia-Verdugo J.M., Berbel P.J. \& López-Garcia C. 1981. Estudio com Golgi y com microscopia eletrônica de los ependimocitos de la corteza cerebral del lagarto Lacerta galloti. Trab. Inst. Cajal 72:269-278.

Garcia-Verdugo J.M., Farinas I., Molowny A. \& López-Garcia C. 1986. Ultrastructure of putative migrating cells in the cerebral cortex of Lacerta galloti. J. Morphol. 189:189-197.
Gomes N. \& Puorto G. 1993. Atlas anatômico de Bothrops jararaca (Wied, 1824) (Serpentes: Viperidae). Mem. Inst. Butantan 55:69-100.

Jessen K.R. 2004. Glial cells. Int. J. Biochem. Cell Biol. 36:1861-1867.

Hartline D.K. 2011. The evolutionary origins of glia. Glia 59:1215-1236.

Kamei Y., Inagaki N., Nishizawa M., Tsutsumi O., Taketani Y. \& Inagaki M. 1998. Visualization of mitotic radial glial lineage cells in the developing rat brain by Cdc2 kinase-phosphorylated vimentin. Glia 23:191199.

Kettenmann H. \& Verkhratsky A. 2008. Neuroglia: the 150 years after. Trends Neurosci. 12:653-659.

Kruger L. \& Maxwell D.S. 1967. Comparative fine structure of vertebrate neuroglial: teleosts and reptiles. J. Comp. Neurol. 129:115-172.

Lazzari M. \& Franceschini V. 2001. Glial fibrillary acidic protein and vimentin immunoreactivity of astroglial cells in the central nervous system of adult Podarcis sicula (Squamata, Lacertidae). J. Anat. 198:67-75.

Ledda M., De Palo S. \& Pannese E. 2004. Ratios between the number of neuroglial cells and number and volume of nerve cells in the spinal ganglia of two species of reptiles and three species of mammals. Tissue Cell 36:55-62.

Monzon-Mayor M., Yanes C., James J.L. \& Sturrock R.R. 1990a. An ultrastructural study of the development of astrocytes in the midbrain of the lizard. J. Anat. 170:30-41.

Monzon-Mayor M., Yanes C., James J.L. \& Sturrock R.R. 1990b. An ultrastructural study of the development of oligodendrocytes in the midbrain of the lizard. J. Anat. 170:43-49.

Mori S. \& Leblond C.P. 1970. Electron microscopic identification of three classes of oligodendrocytes and a preliminary study of their proliferative activity in the corpus callosum of young rats. J. Comp. Neurol. 139:130 .

Peters A., Palay S.L. \& Webster H. de F. 1991. The Fine Structure of the Nervous System. Oxford University Press, New York. 494p.

Quarles R.H., Macklin W.B. \& Morell P. 2006. Myelin formation, structure and biochemistry, p.51-71. In: Siegel G.J., Albers R.W., Brady S.T. \& Price D.L. (Eds), Basic Neurochemistry: molecular, cellular and medical aspects. Elsevier, Amsterdam.

Sofroniew M.V. \& Vinters H.V. 2010. Astrocytes: biology and pathology. Acta Neuropathol. 119:7-35.

Weissman T., Noctor S.C., Clinton B.K., Honig L.S. \& Kriegstein A.R. 2003. Neurogenic radial glial cells in reptile, rodent and human: from mitosis to migration. Cereb. Cortex 13:550-559. 